\title{
RECENT DETERMINATIONS OF FOSSIL PLANTS FROM KENTUCKY LOUISIANA, OREGON, CALIFORNIA, ALASKA, GREENLAND, ETC., WITH DESCRIPTIONS OF NEW SPECIES.
}

By LEo lesQuereux, COlumbes, ohio.

[Compiled and prepared for publication by F. H. Knowlton, Assistant Curator Botany and Fossil Plants, U. S. National Museum. ]

\section{(With Plates IV-XVI.)}

The fossil plants of which the following determinations have been made belong to collections of greater or less extent that have been sent to the U.S. National Museum from various parts of the country. While most of the species are well known, a large percentage of species new to science have been detected, particularly in the collections from Oregon and California.

Following is an enumeration of the various localities from which these plants have been obtained, with an indication (when known) of the geologic horizon to which each belongs :

1. Boaz Station, Graves County, Ky ....... Tertiary (Pliocene).

2. Wickliffe, Ballard County, Ky ............... Lower Eocene.

3. Van Horn's Ranch, John Day Valley, Oregon ........ Miocene.

4. Cherry Creek, Wasco County, Oregon ............. Laramie.

5. Campbell's Quarry, Cross Lake, La ................ Laramie.

6. MeLee's, near Mansfield, La ...................... Laramie.

7. Coral Hollow, Alameda County, Cal............... Miocene.

8. Monte Christo Tunnel, Summit of Spanish Peak, Cal., Miocene.

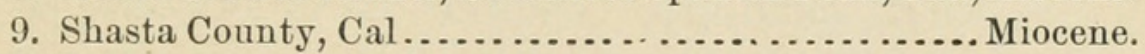

10. Lassen County, Cal......................................

11. Cape Lisbourne, Alaska ..................................

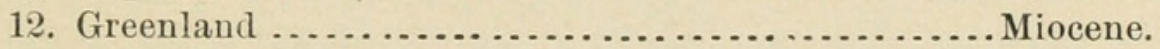

13. Contra Costa County, Cal................. Upper Miocene.

14. Sam's Creek, Jackson County, Oregon ............ Unknown.

15. "Fossil Point, P. Y. Sheet"................... Unknown.

16. Selma, Cherokee County, Tex................. Unknown.

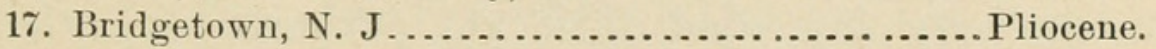

18. Fremont Expedition ......................................

19. "Fortieth Parallel Collection" .................. Unknown.

20. Miscellaneous localities................. Mostly unknown.

1.

Specimens from Boaz Station, Graves County, Ky. Collected by Dr. R. H. Loughridge of the Kentucky Geological Survey. Specimens preserved in a white or purple plastic clay, of the Lagrange group of Safford, probably Upper Tertiary.

Ficus multinervis Heer. Plate Iv, figs. 2, 3.

These leaves have the exact nervation of the species as figured in Ett. Foss. Fl. v. Bilin, part i, Pl. xx, figs. 5, 6, especially like the en- 
larged fig. 6b. The form of the leaf (fig. 2) is like that in Heer Fl. Tert. Helv., vol ii, Pl. Lxxxi, fig. 6, agreeing also by the nervation. The fragment (fig. 3) has epiphytes much like Xylomites aggregatus Heer, Fl. Foss. Aret., vol. vi, Pl, xxıx, figs, 11, 11b. Catalogue number, 2638.

Laurus californica Lx. Plate IV, fig. 1.

Differs from the leares of the species as described and figured (Cret. and Tert. Fl., p. 252, Pl. Lvin, figs. 6-8) in the more obtuse leaf. It is most like Persea amplifolia Sap. (Foss. Fl. of Meximieux, p. 239 [109], Pl. xxvir [xxriii], fig. 1-4). The leaves are larger in the European species and the secondaries and intermediate tertiaries stronger. Catalogne number, 2496.

Sapindus falcifolius Al. Br. Plate Iv, fig. 4.

One specimen; Museum number, 2604.

Quercus $c f$. cuspidata (Rossm.) Ung. Catalogue number, 2573.

Quercus neriifolia Al. Br. Catalogue number, 2574.

2.

Specimens in Claystone from the Lower Eocene or lignitic group. Collected at Wickliffe, Ballard County, Ky., by Dr. R. H. Loughridge of the Kentucky Geological Survey.

Myrica elænoides, n. sp. Plate IV, fig. 5.

Leaf long, linear-lanceolate, entire, gradually tapering at base and somewhat decurring upon a short petiole, acute or acuminate (point broken); secondar ies close, numerous, oblique, camptodrome; tertiaries intermediate, more inclined, anastomosing at right angles on both sides, reticulation very small, quadrate.

The form of this fine leaf is like that of a Salix (e. g., S. tabellaris Lx. Miss. Fl., Pl. xvır, fig. 4), being a little narrower and more gradually narrowed to the petiole. The nervation is also analogous, but secondaries are more numerous and more oblique. By its form also the leaf has great affinity to Quercus elana Ung. (especially as figured in Sap. Etudes iii, Pl. II, fig. 20, for the form, and pl. v, fig. 2 for the nervation), differing, however, by the rery close small quadrate, punctate areolation. The aspect is also that of a Laurus, the areolation being that of Laurus canariensis Willd. It appears more likely referable to Myrica, the tertiary nervation being that of Myrica aquensis (Sap. Etudes iii, Pl. vir, fig. 7), and the form that of M. hakeofolia (Sap. Etudes ii, Pl. v, fg. 9).

\section{Sapindus angustifolius $\mathrm{Lx}$.}

Two specimens; Museum number, 2599.

\section{Sapindus dubius Ung.}

Eight specimens; Museum number, 2603.

Myrica Copeana Lx.

One specimen; Museum number, 2521. 
Juglans rugosa $\mathrm{Lx}$.

One specimen; Museum number, 2490.

Salix angusta Al. Br.

Two specimens; Museum number, 2588.

Salix media Heer.

Three specimens; Museum number, 2593.

Quercus Saffordii Lx. Plate v, figs. 1-3.

The description of the species is given in Geol. Tenn., p. 427, pl. K, figs. $2 a, 2 b, 2 c$.

It is comparable, indeed much like the small leares referred to Quercus furcinervis Rossm. by Engelhardt (Fl. v. Leitm., p. 402 [62], Pl. $x x v[x]$, figs. 10-19), which differs from the American form in having the secondaries more regular, at equal distances, and not separated by tertiaries, which do not correspond to teeth of the borders but are shorter, camptodrome, or ending in the areolation. From the de. scription of Engelhardt and the figures of Quercus furcinerris in Ett. Foss. Fl. v. Bilin, Th. I, Pl. xvI, figs. 11, 12, Quercus saffordii Lx. appears to be a mere variety of that very common and variable species.

Ten specimens; Museum number, 2571.

Porana species.

One specimen; Museum number, 2630.

3.

Specimens from Van Horn's ranch, John Day Valley, Oregon, collected by Capt. Charles Bendire, U. S. Army. The age of these beds is Miocene, probably latest Miocene.

Magnolia lanceolata Lx.

One specimen; Museum number, 2514.

Magnolia Inglefieldi Heer. Fl. Art. I, p. 120, Pl. xviII, figs. 1-3.

I refer the specimen to the species with some doubt, as Heer describes the leaves as having a thick medial nerve, being coriaceous and the surface polished. In these leaves, which are, however, impressions of the lower surface, the medial nerve is comparatively thin, though thick, proportionally, to the secondaries; the texture is not coriaceous and the surface is not polished. The nervation is, however, of the same type; the secondaries distant; the areas broad, the nervilles or tertiaries distinct, and the areolation very small, quadrangular, pitted by points as in fig. $3 a$ of Heer; it must be remarked also that fig. 1 of Heer has not the medial nerve broader than of the leaf in specimen.

One specimen; Museum number, 2513,

Liquidambar protensum Ung. Plate vir, fig. 3,

The leaf has the characters of the species as represented in Heer, Fl, Tert. Helv., p. 8, Pl. III, fig, 11. It is, however, deformed by maceration, the medial nerve of the middle lobe being displaced from its point of 
conjunction with the lateral ones; and the borders being all totally erased so that their characters can not be observed except at the lower borders of the left lobe, which is serrate. Heer describes the leaves as coriaceous. These specimens show them to be thin and pellucid, an appearance, however, which may have been produced by maceration. In comparing this leaf with that of Acer dimorphum, one can but find between them a remarkable ana!ogy of characters, the lower lateral lobes, though comparatively very small in Pl. Ix, fig. 1, being marked on the lower side each by a few small teeth or like serrate, while the nervation of the upper lateral lobe is about of the same character.

Two specimens; Museum number, 2504.

Liquidambar europeum Al. Br.

One specimen; Museum number, 2503.

Acacia oregoniana, n. sp. Plate v, fig. 4.

Legume long pedunculate, $8^{\mathrm{cm}}$ long, $1 \frac{1}{2} \mathrm{em}$ broad, linear, narrowed at one end to a loug pedicel, obliquely rounded at the other to a pointed one-siled beak; bearing 8 to 9 small oval seeds more or less distant, joined to the upper borders by simple filaments; borders, narrow; legume, flattened by compression, membranous.

The legume is larger than any of those figured by Heer (Fl. Tert. Helv., Pls. Cxxxix and (xL), except the fragment of A. microphylla, Pl. CXL, fig. 8 . Its form is that of Cercis occidentalis, but the borders are not winged by a membrane.

Two specimens; Museum number, 2412.

Acer Bendirei, n. sp. Plate v, fig. 5, vi, fig. 1, vir, fig. 1, viII, fig. 1. Acer trilobatum productum Al. Br. Lesquereux in Cret. and Tert. Fl., p. 253, Pl. Lix, figs. 1-4.

Leares large, palmately trilobate, cordate or round auricled at base, with a very long, thick petiole; lobes long and comparatively narrow, the medial twice as long as the lateral ones, which are erect, at a very acute angle of divergence or even curved inward, dentate from the base; teeth either large and long, sharply acuminate, or shorter, turned outward and merely pointed.

The leaf, tig, 1, Pl. vi, has no auricie at its base, and the teeth of the lobes are large and sharply acuminate; thus, it seems at first to belong to a marked variety or a different species. But that of tig. 5, Pl. v, has some of the teeth also sharply acuminate, and at base a short auricle or rather a prolongation of the lamina lower than the point of union of the primary nerves. The petiole is thick, inflated, and split at base by compression.

Acer trilobatum, var. productum, Al. Br., has the medial lobe nearly as long as in those of this species, which evidently differs by the base of the leaves, cordate or auriculate, by the narrow rery oblique lateral lobes sometimes curred inward, and the sharply acuminate teeth. Acer Heerii (Mass. Flor. Foss., p. 345, Pl. xvi, and XvII), a syuony $m$ of A. trilobatum productum $\mathrm{Al}$. Br., is represented with leaves sometimes 
auricled at base, but the lateral lobes are open with short even obtuse teeth of a far different facies.

Eleven specimens; Museum number, 2413.

Acer dimorphum, n. sp. Plate Ix, fig. 1.

Leaves large, palmately three-lobed; lobes oblong, lanceolate, distantly obtusely dentate, the lateral shorter, half open, prolonged at base into two short triangular minutely dentate lobes or large teeth.

The leaf has a peculiar facies, the medial lobe being large and long; obtusely dentate, with few distant secondaries, and also few distant obtuse teeth, while the lateral lobes open, direrging 50 degrees from the medial nerve, have short obtuse teeth, numerous camptodrome or craspedodrome secondaries, and are prolonged at their base into small lobes opening like wings on both sides of the medial nerve.

The relation of this leaf is with Acer grosse-dentatum Heer Fl. Tert. Helv., iii, 54, Pl. CxII, fig. 24), from which it differs by the pecurliar characters of the lateral lobes.

Two specimens; Museum number, 2415.

Acer, fruits of. Plate vi, figs. 2, 3; vir, fig. 2.

Seeds long and large-winged, broad-margined on the outer side; nucleus large, apparently round (crushed).

The seeds are comparable to those of Acer dasycarpoides Heer (Fl. Tert. Helv., vol. iii, Pl. CLV, fig. 7), the wings being, however, rounded, not emarginate at the middle. They most resemble those of Acer dasycarpum Ehrh. of the eastern slope of the United States, and those of A. macrophyllum Pursk, of California. The margin of the outer side is, however, less enlarged and less compact at base in the living than in the fossil seeds. These are most probably referable to the preceding species.

Three specimens; Museum number, 2417.

Acer, branches of?

Five specimens; Museum number, 2418.

Sapindus angustifolius $\mathrm{Lx}$.

Two specimens; Museum number, 2598.

Rhus Bendirei, n. sp. Plate Ix, fig. 2.

Leaf compound, leaflets oblanceolate, narrowed from below the middle to a short petiole, tapering above to an acute point, serrate to near the base; medial nerve stout; secondaries parallel, curved in travers. ing the blarle; branching near the borders, craspedodrome with their divisions. The leaflet is apparently a terminal one, longer and more narrowed downward than the lateral ones. To these I refer a small oblong lanceolate leaflet, rounded in narrowing rapidly to the point of attachment, very short petioled, with small teeth, and areolation identical. The substance of the leaves is membranous; the areolation distinct, rery small, irregularly round or angular,

Three specimens; Museum number, 2582. 
Berchemia multinervis $\mathrm{Al}$. Br.

Two specimens; Museum number, 2438.

Aralia! pungens? Lx.

One specimen; Museum number, 2428.

Aralia! whitneyi? Lx.

- One specimen, Museum number, $24: 9$.

Andromeda? (Leucothœ) crassa, n. sp.

Leaves thick, coriaceous, entire, narrowly oval, oblong or elliptical, obtuse, petioled. Secondaries camptodrome. This leaf resembles those of some Quercus, e.g., I. chlorophylla Ung.; but the secondaries are not thin and indistiuct, but comparatively thick, well marked, somewhat distant, camptodrome, the borders of the leaf being reflexed aud the end of the secondaries not seen. Its greatest affinity is with the leaf figured by Unger (Sylloge, iii, p. 36, Pl. xI, fig. 11) as Andromedatristis, a variety, according to Schimper, of $A$. protogaea. The leaf is $5^{\mathrm{cm}} \operatorname{long}$, $22^{\mathrm{mm}}$ broad at the middle, with a petiole a little more than $1^{\mathrm{cm}}$ long; the secondaries, 6 pairs, diverge 40 to 50 degrees from the medial nerre.

One specimen; Museum number, 2422. On same stone with numbers 2480 and 2614 .

\section{Cassia phaseolites? Ung.}

Two specimens; Museum number, 2455.

Paliurus columbi Heer.

One specimen; Museum number, 2542.

Myrica (Aralia) lessigii? Heer.

Two specimens; Museum number, 2522.

Porana Bendirei (Ward) Lx. Plate vin, fig. 4. Marsilia Bendirei Ward. Sketch of Paleobotany. Fifth Ann. Rept. Director U. S. Geological Survey, 1883-'84. p. 446.

Calix large, quadrilobate, lobes broadly oval, obtuse; the lateral shorter, more enlarged, reniform, counate to above the middle, nerves thin, diverging from a central small oval point.

The calix is nearly $4^{\mathrm{cm}}$ wide in its length, $3^{\mathrm{cm}}$ broad ; the largest of the sepals being $2^{\mathrm{cm}} \operatorname{long}, 1 \frac{1}{2} \mathrm{~cm}$ broad at the middle. The species is much like $P$. oningensis (as figured by Weber in Paleontog., vol. ii., Pl. xxiv, fig. 2), a species which, according to Schimper, is not the true $P$. aningensis and which differs from the American species by having the sepals free to the base or to near the center, smaller aud round. That plant of Weber is apparently what is described as Hydrangea sagoriana Ett. (Foss. Fl. v. Sagor, part iii, p. 18, Pl. xxxI, fig. 3).

Two specimens; Museum ninmber, 2541.

Carpites fragariæformis, и. sp.?

One specimen; Musenm number, 2442, 


\section{Salix varians Göpp.}

One specimen; Museum number, 2596.

Salix raena? Heer.

Two specimens; Museum number, 2594.

Salix Engelhardti, n. sp. Plate viri, fig. 2.

Leaves oblanceolate or narrowly obovate, rounded to the point (broken), gradually narrowed to the base; borders serrate with short appressed teeth; medial nerve narrow, secondaries equidistant, camptodrome, and parallel from the base.

The leaf, $\mathrm{S}^{\mathrm{em}} \mathrm{long}, 3^{\mathrm{em}}$ broad toward the apex, is gradually narrowed to the petiole. Except for the secondaries, which are open at an angle of divergence of 50 to 60 degrees curred in passing toward the borders, the areolation is obsolete. It is comparable by its form, the dentation of the borders, and its nervation to the living Salix discolor Muhl.

Two specimens; Museum number, 2589.

\section{Salix amygdalifolia $\mathrm{Lx}$.}

Two specimens; Museum number, 2587.

Quercus Horniana, n. sp. Plate v, fig. 6.

Leaves small, subcoriaceous, elliptical oblong, narrowed upward to a point, rounded to a short, thick petiole, obtusely dentate; medial nerve thin; secondaries at an acute angle of divergence, simple, straight to the point of the teeth, numerous alternate and parallel; the two lowest pairs more open, slightly curved back, and with few branches.

The angle of divergence of the secondaries is 30 degrees; they are eomparatively thick, less than $5^{\mathrm{mm}}$ distant. The appearance of the leaf is like that of a Castanea, but no species of this genus has the leaves so short dentate and the secondaries ramified. It is most like Dryophyllum (Quercus) Bruneri Ward (Synop. of the Fl. of the Laramie Group, Pl. xxxvII, figs. 6-9), from which it differs essentially by the small size, the secondaries straight, even slightly curved backward rather than upward and the lowest ramified. It is also comparable to Quercus densiflora Hook \& Arn. (Bot. Beechey, p. 391, of California), but has the leaves comparatively shorter, not tapering, but rounded at base.

One specimen; Museum number, 2556.

Quercus pseudolyrata Lx. Plate x, fig. 1. (Foss. Pl. of the Aurif. Gravel, p. 8, Pl. II, figs. 1-2.)

The leaves are cut into deep, oblong linear or lanceolate lobes, pointed or acuminate. With this exception the description $l . c$. is correct.

Twelve specimens; Museum number, 2565.

Quercus pseudolyrata Lx., var. acutiloba n, var. Plate XI, fig. 1.

Four specimens; Museum number, 2566.

Quercus pseudolyrata Lx., var. angustiloba n. var. Plate XI, fig. 2.

One specimen; Museum number, 2567.

Proc. N. M. $88-2$ 
Quercus pseudolyrata Lx., var. brevifolia, n. var. Plate x, fig. 2.

One specimen; Museum number, 2568.

Quercus pseudolyrata Lx., var. latifolia, n. var. Plate XII, fig. 1.

Two specimens; Museum number, 2570.

Quercus pseudolyrata Lx, var. obtusiloba, n. var. Platex, Fig. 3.

Two specimens; Museum number, 2569.

Populus glandulifera Heer.

Is right according to Schimper's deseription and also to my figures of the species in "Cret. and Tert. Fl." Pl. XLVI, fig. 4, which is better than any of Heer's (Fl. Tert. Helv., Pl. LvIII), the secondaries boing at a much greater distance from the primaries as figured by Heer, and also much thinner.

One specimen; Museum number, 2545.

Populus mutabilis Heer.

One specimen ; Museum number, $2547 \frac{1}{2}$.

Fagus castaneæfolia Ung.

Two specimens; Museum number, 2466.

Carya elænoides Heer.

One specimen; Mnseum number, 2446.

Carpinus grandis Ung.

One specimen; Museum number, 2440.

Carpinus pyramidalis Heer.

One specimen; Museum number, 2439.

Alnus Kefersteinii Ung.

Four specimens; Museum number, 2420.

Ulmus plurinervia Ung.

Two specimens; Museum number, 2620.

Ulmus californica $\mathrm{Lx}$.

One specimen; Museum number, 2621.

Ficus? oregoniana, n. sp. Plitte Ix, fig. 3.

Leaves ovate, taper pointed, enlitrged at and below the middle; rounded to a short thick petiole, entire, merlial nerve narrow, secondaries alternate, distant, much curved in passing to the borders, campto. drome, separated by thin tertiaries composing the areolation in anastomosing with oblique nervilles, meshes very irregular.

The areolation is somewhat indistinct, the petiole is short, much enlarged at its point of attachment, scarcely $1^{\mathrm{cm}}$ long. The relation of this leaf is with Ficus maravignce, (Mass. Fl. Foss., Pl. xxxI, f. 7), which is smaller, less enlarged in the lower part, but apparently with the same kind of nervation.

Two specimens; Museum number, 2475. 
Planera Ungeri Ett.

Two specimens; Museum number, 2534.

Platanus Raynoldsii Newby.

Two specimens; Museum number, 2539.

Platanus nobilis Newby.

One specimen; Museum number, 2 ก38.

Platanus aceroides (Göpp) Heer. Plate v, fig. 7 .

Two specimens; Museum number, 2535.

Smilax Wardii, n. sp. Plate xıI, fig. 1.

Leaf long, linear-lanceolate, gradually narrowed above to an acute point, hastate sagittate at base, 5 to 7 nerved from the base of the medial nerve.

The blade of leaf is about $14^{\mathrm{cm}}$ long, $2^{\mathrm{cm}}$ broad below the middle, with two pairs of secondaries or lateral nerves emerging from the base, the inner more distinct at an acute angle of divergence, passing up in the middle of the areas, parallel to the midrib and acrodrome, the outer pair emerging from the base nearly at right angles dividing at the middle in two branches, the one directed upward from which depends the the outer, thin secondaries, which follow close to the borders, being gradually effaced above, the other descending into the auricle by branchlets, there curving down and around, anastomosing in following the borders, with thin nervilles emerging from the base of the midrib. The areolation is made of thin nervilles oblique to the secondaries and crossing obliquely in rhomboidal meshes.

Related by its prolonged rounded auricle to the numerous sagittate species of Smilax, the leaf differs from all by the very long linear lan: ceolate blade, the obtuse auricles descending $2^{\text {сг }}$ below the base of the midrib, diverging from each other at an angle of 55 to 60 degrees.

Three specimens; Museum number, 2613.

Phagmites oeningensis $\mathrm{Al}$. Br.

Six specimens; Museum number, 2530.

Glyptostubus Ungeri Heer.

Fifteen specimens; Museum number, 2480.

Sequoia Nordenskiöldi Heer.

Two specimens; Museum number, 2610.

Sequoia Langsdorfii Heer.

Two specimens; Museum number, 2607.

Taxodium distichum miocenum Heer.

Six specimens; Museum number, 2614. 
4.

Specimens from Cherry Creek, Wasco County, Oregon, collected by Capt. Charles Bendire, U. S. Army. Age probably Eocene (Laramie group).

\section{Rhamnus obovatus Lx.}

Three specimens; Museum number, 2579.

\section{Rhamnus Dechenii Web.}

Two specimens; Museum number, 2575.

\section{Rhamnus Cleburni Lx., var.}

A large fragment, merely differing from the normal form by the nervilles more oblique nearly at right angles to the medial nerve and slightly more distant. The form of the leaf, of which one side is preserved, is conformable to that of the figures of the species in Lesqx. (Cret. and Tert. Fl., Pl. LIII, figs. 1, 2), made from specimens from Golden, Colo. rado.

One specimen; Museum number, 2580.

Magnolia lanceolata Lx.

One specimen; Museum number, 2515.

Andromeda protogaea Ung.

One specimen; Museum number, 2423.

Aralia digitata Ward. Plate xI, figr. 4.

Leaves small, palmately five-lobed to the middle, trinerved from above the base, either cuneiform, subcordate, or prolonged into a short tridentate pelta; lobes linear lanceolate, denticulate in the upper part, separated by narrow, obtuse sinuses; secondaries numerous, camptodrome or craspedodrome, entering the teeth in the upper part of the lobes.

This rery fine species is represented by four nearly entirely preserved leaves in Ward's Synop. of the Flora of the Laramie Group, Pl. XLVII, figs. 10-12, and Pl. XLıx, fig. 1. From these figures the leaves appear extremely variable in size, the whole leaf (fig. 12) being only $8 \frac{1}{2} \mathrm{~cm}$ long, including a thick petiole more than $2^{\mathrm{cm}}$, with lobes $3^{\mathrm{cm}}$ long and $1^{\mathrm{cm}}$ broad, while another figure.(Pl. xLIx, fig. 1) represents part of a leaf at least $16^{\mathrm{em}}$ long with lobes $10^{\mathrm{cm}} \mathrm{long}$ and $5^{\mathrm{cm}}$ brodul above the middle, the lobes being generally slightly narrowed from the upper part toward the sinuses.

The relation of this species is like that of $A$. gracilis and $A$. notata Lesqx., of the Laramie group and especially with A. Saportanea Lesqx., of the Dakota group. The specimens from Cherry Creek have the lower part of the leaf destroyed.

Une specimen; Museum number, 2424.

Aralia notata Lx.

One specimen; Museum number, 2426. 
Ilex longifolia Heer.

One specimen; Museum number, $\longrightarrow$.

Diospyros lancifolia Lx.

One specimen; Museum number, 2461.

Cornus ferox Ung.

One specimen; Museum number, 2452.

Carpites cinconæ, n. sp.

Une specimen; Museum number, 2440.

\section{Populus monodon Lx.}

The leaf has the form of those of P. Gaudini Fisch-Oost. and also the size, but the nervation is more open and the leaf is not acuminate. It is also coriaceous, a character not indicated by Heer. The species appears to be an American form, perhaps identical, or at least closely allied, to the European $P$. Gaudini. It has by its nervation a relation to Populites Gasparinii, Massal (Flor. Foss., Pl. xxvin, fig. 3), and also to the leaf or fragment figured by Heer (Fl. Foss. Arct., vol. I, Pl. L, fig. 7) as Phyllites evanescens, especially like it by the nervation more open or nearly at right angles in the upper part.

Two specimens; Museum number, 2546.

Salix Schimperi, n. sp. Plate XIII, fig. 5.

Leaves membraneous, large, lanceolate, gradually acuminate, narrowed in rounding to the subcordate base, minutely serrulate all around ; nerves thin, open.

The nervation and areolation of this fine leaf are distinctly of a Salix. The membraneous leaf is thin and in being wetted distinctly shows the characters of the nervation and areolation. It is $15 \frac{1}{2} \mathrm{~cm} l o n g, 3 \frac{1}{2} \mathrm{~cm}$ broad at a short distance above the base, from which point it is gradually narrowed and tapers by a curve to a short petiole, being subcordate at base, as in S. cordato lanceolata of Al. Br., figured by Heer (Fl. Tert. Helv., vol. ii, Pl. Lxvint, fig. 5). The petiole is apparently thick, but is mostly covered. The crenulations of the borders though distinct are very small, turned upward as in S. Lavateri Heer (FI. Tert. Helv., vol. ii, Pl. Lxvi, figs. 1-12). The leaf is not inclined nor curved, but perfectly equilateral.

The leaf is clearly related to S. cordato-lanceolata Al. Br., but it is twice as large, more distinctly crenulate, thin, membraneons, and the base is less broadly cordate.

Heer remarks that no fossil Salix leaves of this character have as yet been discovered, and that Braun's species needs coufirmation to fix the character of the subcordate base, which may be only the variation of a single leaf. No other leaf of Salix has been found as yet with this one except $S$. varians, which has the leaves sometimes as large as this, but always narrowed to the base and not rounded and subcordate.

Two specimens; Museum number, 2595. 


\section{Castanea Ungeri ? Heer.}

Three specimens; Museum number, 2447.

Quercus furcinervis (Rossm.) Ung.

One specimen; Museum number, 2554.

Quercus lonchitis Ung.

Three specimens; Museum number, $2557 \frac{1}{2}$.

Quercus fraxinifolia $\mathrm{Lx}$.

One specimen; Museum number, 2552.

Quercus Olafseni Heer.

One spevineu; Museum number, 2559.

Quercus platania Heer.

One specimen; Museum number, 2563.

Juglans Leconteana Lx.

One specimen; Museum number, 2487.

Juglans rhamnoides Lx.

Two specimens; Museum number, 2483.

Juglans rugosa Lx.

Two specimeus; Museum number, 2489.

Juglans vetusta Heer.

There is no difference at all, either in the form, the size, or the nervation, between this leaf and that figured in Heer, Fl. Tert., rol. iii, Pi. exxvii, fig. 41, described, p. 90, as leav es petioled, very entire, oblong, obtuse at apex; secoudaries ten to twelve pairs. Heer says that these leaves may represent a variety of the very variable Juglans acuminata which, under the names of Juglans rugosa Lx., is quite as common in the Laramie Group as J. acuminatu is in the European Tertiary. The secondaries are very open, nearly at right angles, the reticulation distinct, in large polygonal areoles, formed by subdivisions of intermediate thinner tertiaries or nervilles.

One specimen; Museum number, 2636.

Juglans denticulata Heer.

One specimen; Museum number, -

Phyllites wascoensis, v. sl. Plate xiv, fig. 3.

Leaves comparatively large (the lower half of one only is preserved), oval or ovate, cuneiform and abruptly rounded, truncate at base; secondanies oblique, straight in passing toward the borders, parallel, joined by strong nervilles, obliquely directed upwards.

The leaf, broken $6^{\mathrm{cm}}$ from the base, is at the point of fracture $6^{\mathrm{cm}}$ broal. The fragment has six pairs of secondaries, the three lower coming close together toward the base, where they are scarcely $4^{\mathrm{mm}}$ distant, while above the distance is 1 to $1 \frac{1}{2} \mathrm{~cm}$. The distribution of the second. aries and of the nervilles tending upward, finds analogy in some leaves 
of Cornus, like $C$. Studeri Heer, of the Fl. Tert. Helv., vol. iii, Pl. Cv, figs. 18-21, or the European C. mas. Linn., species in which the lower secondaries are often more proximate toward the base; but as the upper secondaries are directed toward the borders and branching, the fragments ean not be referable to Cornus. It might be compared also to species of Rhamnus, but the lowest secondaries branch and curve in bows along the borders, a character which is at variance with that of the secondary nervation of the leaves of that genus.

One specimen; Museum number, 2633.

\section{Ficus tenuinervis $\mathrm{Lx}$.}

The specimen of Cherry Creek is better preserved than the small fragment of this species in Lesqx., Cret. and Tert. Fl., p. 164, Pl. xLIV, fig. 4. The leaf is large, cordiform, rounded at apex, apparently obtuse or obtusely pointed, largest below the middle and rounded to the sub. cordate or emarginate base. The secondaries are distant, parallel, much curved, following close to the borders in simple areoles joined by strong nervilles at right angles forking obliquely or at right angles at the middle, subdivided again into small irregular polygonal areoles. The characters of nervation, as well as the primary reticulation, is exactly represented in $l$.c., fig. 4. But the leaf of Cherry Creek is more than twice as large, 7 to $8^{\mathrm{cm}}$ long, and as broad below the middle, with five pairs of secondaries at a broad angle of divergence.

One specimen; Museum number, 2479.

\section{Equisetum Hornii, n. sp.}

Stems thick with branches $1 \frac{1}{2}$ to $2^{\mathrm{cm}}$ in diameter, not compressed; one stem compressed $3^{\mathrm{cm}}$; articulations distant; sheaths appressed, short, merely obtusely dentate; teeth generally obsolete and destroyed, lingulate, connate to near the inflated apex; articulations uncler it or at its base marked by round scars of leaves distinctly and deeply striate; stems nearly smooth or obscurely striate; diapbragm thick, often left separated from the crushed stems, coriaceous.

The largest fragment preserved of this species is $11^{\mathrm{cm}}$ long; the di tance between the articulations $8 \frac{1}{2} \mathrm{~cm}$; that of the branches $1 \frac{1}{2}$ to $2^{\mathrm{cm}}$ long, according to the size. The width of the striæ-which are fiat in the lower part, grooved in the upper-is 1 to $1 \frac{1 \mathrm{~mm}}{4}$. The sheaths seen upon a fragment of specimen, the inside of which is preserved, is $2^{\mathrm{mm}}$ long, fringed with oblong and pointed short teeth. The roots are thick, $1 \frac{3}{4} \mathrm{~cm}$ in diameter.

Except Equisetum procerum Heer (Fl. Tert. Helv., vol. iii, p. 258, Pl. cxlvi, fig. 1), no species described from the Cenozoic time may be compared to this. From E. procerum it differs merely by the sheaths being longer, the teeth and striæ much narrower. The teeth of the sheaths, as described by Heer, are short, muticous. The fragments from Oregon are apparently merely branches, at least those which have not been flattened by compression, two of which are narrowed to the base and 
obtuse-like branches. The largest fragment, flattened, $3^{\mathrm{cm}}$ in diameter, is as large as that figured by Heer. The character taken from the size of the stem is of no great value; these fragments may represent the same species as that of Heer, for one fragment (No. 733) has a whole sheath and the stem above, partly preserved, is striate. It may be also the species mentioned or described as E. robustum Newb'y (Boston Journ. Nat. Hist., 1863).

Forty-one specimens; Museum number, 2464, 2465.

\section{Lygodium neuropteroides Lx.}

According to Gardner and Ett. this is L. Kaulfussi Heer (Flor. von Skopau; Beiträge zur näher. Kenntniss d'Sachs Thüringen Braunkohle, p. 409 [2], Pl. VIII, fig. 21; Pl. Ix, fig. 1, 1861). Heer's species is made of a mere fragment of a lobe, which appear's deutate and linear with lateral nerves much more oblique aud distant so that the reference of the American leaves to the European species is very doubtful. Schimper has not admitted or deseribed it in his Paleontologie Vegetale.

Sixty specimens; Museum number, 2505.

Pteris subsimplex Lx.

One specimen; Museum number, 2634.

\section{5.}

Specimens from Camplell's Quarry, Cross Lake, La. Collected by Mr. L. Johnson. Age probably Eocene, the equivalent of the Lagrange group of Sifford (Laramie group?).

Sapindus angustifolius $L x$.

One specimen; Museum number, $2600 \frac{1}{2}$.

Sapindus caudatus Lx.

One specimen; Museum number, 2601.

Sapindus coriaceus $\mathrm{Lx}$.

One specimen; Museum number, 2602.

Magnolia laurifolia Lx.

The leaf is fully preserved, the borders only somewhat erased. It is $19^{\mathrm{cm}}$ long, gradually enlarged from the rounded base to below the apex, and there rapidly tapering to the obtusely pointed apex. It has twenty secondaries, all parallel, equidistant as in Miss. Fl., Pl. xx, fig. 1 , having the same degree of divergence, 50 degrees, as in fig. 2.

Three specimens; Museum number, 2517.

Laurus socialis Lx.

One specimen; Museum number, 2501.

Laurus utahensis Lx.

Two specimens; Museum number, 2502.

Rhamnus Cleburni Lx.

One specimen; Museum number, 2581. 
Rhamnus Eridani Ung.

One specimen; Museum number, 2578.

Carya antiqua? Ny.

Eleven specimens; Museum number, 2443.

Quercus angustiloba $\mathrm{Al}$. Br.

One specimen; Museum number, 2551.

Quercus Moorii? Lx. The species is figured from three specimens in Miss. Foss. Flo., Pl, xvi, figs. 1-3. Of these specimens none are alike; they all differ much by the size, the more or less curved nerves, being only identified by the peculiar short blunt teeth, separated by very shallow or straight sinuses. In this specimen the leaf greatly differs by the acuminate apex, while none of the three specimens of the Mississippi has the apex preserved, only in one, fig. 3, the apex being erased, appears blunt. Considering the affinity of nervation and identity of dentation, I refer the leaf to the species of the Mississippi Flora, which still has other species identical with those of Campbell's Quarry, Cross Lake, near Shreveport, La.

\section{Ficus goldiana Lx.}

One specimen; Museum number, 2471.

Ficus goldiana Lx., var.

One specimen; Museum number, 2472.

Ficus spectabilis $\mathrm{Lx}$.

Three specimens; Museum number, 2476.

Phragmites œningensis Al. Br.

One specimen; Museum number, 2532.

6.

Specimens from McLee's, 2 miles north of Mansfield, La. Collected. oy Mr. L. Johnson. Age, the same as the preceding lot of specimens.

Magnolia laurifolia $\mathrm{Lx}$.

Two specimens; Museum number, 2516.

Ficus spectabilis $\mathrm{Lx}$.

Two specimens; Museum number, 2476.

Aralia, fragment.

One specimen; Museum number, 2431.

'latanus Guillelmæ Göpp.

$\%$.

Specimens from the north side of Corral Hollow, Alameda County, al. Collected by Mr. H. W. Turner.

Specimens in soft hardened white clay, with conchoidal fracture, epresenting only small fragments of leaves. The age is Miocene. 
Laurus californica Lx.

Eight specimens; Museum number, 2494.

Laurus resurgens? Sap.

Twelve specimens; Museum number, 2578.

Laurus Furstenbergii Al. Br.

Seven specimens; Museum number, 2597.

Persea pseudo-carolinensis $\mathrm{Lx}$.

One specimen; Museum number, 2628.

Persea punctulata, n. sp. Plate xIv, fig. 1.

Leaves oblanceolate, pointed at apex, gradually narrowed to the short petiole, thickish but not coriaceous, medial nerve strong, second aries at an acute angle of divergence, eurving in passing toward the borders, which they follow in a series of simple areoles, parallel, equi distant, about ten pairs; nervilles thin, nuinerous, at right angles areolation irregularly polygonal or quadrangular, minutely punctulate

The leaves have a great degree of likeness to those of Persea pseudo. carolinensis Lesqx. (in Fl. of the Gold Gravel of California, Pl. viI, fig. 1,) differing merely by being less rounded and narrower at the middle longer subdecurring to the somewhat broad and round petiole. $1 \frac{1}{2} \mathrm{cu}$ long. The divergence of the secondaries, which is about the same from the base upward, is 40 to 45 degrees. The essential character which indicates a separation of this species from the numerous specimens of Laurineæ which are represented in fragments and seen to constitute the whole flora of Corral Hollow, is the small points irregularly strewn upon the surface of the leaves appearing upon the epider. mis as prominent, and under it, or upon the stone, as hollow. They look like points of hairs, but are not areoles of the leaves, as they are very small and irregular in position and distance. For the secondaries and the form of the leaves the species is comparable to Laurus superba Sap. (Etude II, 2, Pl. VII, fig. 4; III, 1, Pl. xv, fig. 5). The areolation differs in being much larger than it is marked in this last quoted figure.

Fifteen specimens; Museum number, 2529.

Rhus Henfleri? Heer.

Oue specimen; Museum number, 2583.

8.

Monte Christo Tunnel, summit of Spanish Peak, Cal. Collected by Mr. J. S. Diller. Age, Upper Miocene.

Acer Bendirei, n. sp. (See ante, p. 14.)

Four specimens; Museum number, 2414.

Laurus californica Lx.

One specimen; Museum number, 2495. 
Myrica Ungeri Heer.

One specimen; Museum number, 2523.

Platanus dissecta Lx.

One specimen; Museum number, 2536.

Pterospermities spectabilis Heer.

One specimen; Museum number, 2550.

\section{Carya bilinica Ung.}

After due reconsideration I admit these leaves as referable to Carya bilinica Ung. The only difference, in considering the figures and descriptions of authors, is that in these leaves the secondaries which run high along the borders appear to end into the small acute teeth, with a branch passing under the teeth and continuing upward close to the borders and along them. The leaves rather look like the form which Unger has figured in Silloge, Pl. xvir, as Carya Ungeri Ett. Same kind of nervation is seen in Juglans cinerea, which has, however, the secondaries less oblique.

One specimen; Museum number, 2444.

\section{9.}

Shasta County, Cal. Collected by Mr. J. S. Diller. Age, Miocene.

Persea Dilleri, n. sp. Plate xin, figs, 2-4.

Leaves elliptical or oblong, graduailly narrowed to a long petiole, obtusely pointed, entire and subcoriaceous ; secondaries distant, parallel, thin, curving in traversing the blade and along the borders, the upper ones more curved.

The leaves about $8^{\mathrm{cm}}$ long, $3^{\mathrm{cm}}$ broad at the middle, have 7 or 8 pairs of secondaries at an angle of divergence of 40 degrees with a petiole $3^{\mathrm{em}}$ long, thick, eularged at the point of attachment. Toward the apex of the leaves the secondaries are much curved, nearly in half circle, separated by tertiaries or rather nervilles at right angles to the medial nerve, forming by anastomoses very small quadrangular areolation as in species of Persea or Laurus. The lowest pair of veins are slightly more oblique than the others, which are all nearly opposite.

By the shape of the leaves, obtuse at apex, and by the areolation, the species is related to Persea caroliniana, var. palustris Chapman, from which it differs by the leaves being slightly shorter, the secondaries at a more acute angle of divergence, and the petiole longer by $1^{\mathrm{cm}}$.

Viburnum Wymperi Heer.

Specimen discarded.

Carya bilinica Ung.

Two specimens; Museum number, 2445.

Alnus Kefersteinii Al. Br.

One specimen; Museum number, 2420. 
Ficus microphylla Lx.

One specimen; Museum number, 2473.

Ficus shastensis n. sp. Plate XI, fig. 3 .

Leaf subcoriaceous, oval, a cuminate, narrowed to an enlarged slightly winged petiole; secondaries obliquely curved, anastomosing in simple bows near the borders; areolation very small, closely granulose, verrucose.

The leaf $6^{\mathrm{cm}} \operatorname{long}, 3 \frac{1}{2} \mathrm{~cm}$ broad at the middle, is tapering upward to a short acumen, rounded and narrowed downward about in the same degree to a broad petiole $15^{\mathrm{mm}}$ long, enlarged at the point of attachment. In shape anl size the leaf is like that of Persea Braunii Heer (figured in Fl. Tert. Helv., vol. iii, Pl. CLII, fig. 2), and the distribution of the secondaries is also the same. But the leaf is corered by a rerrucose surface exactly similar to that of Ficus scabriuscula Heer l. c. (ii, p. 64), which, as the author says, is often marked upon the leaves of species of Ficus, rendering their surface rough, and covering the areolation. This kind of verrucose process is quite distinct under the glass. The bows of the secondaries along the borders are also typical of species of Ficus as well as the broad petiole.

Two specimens; Museum number, 2478.

10.

Lassen County, Cal. Collected by Mr. J. S. Diller. Age, Eocene (Laramie).

Aralia lasseniana, n. sp. Plate xıv, fig. 5.

Leaflet linear, oblong, rounded at base to a short petiole, entire or undulate on the borlers, subcoriaceous, penninerved; secondaries distant and equidistant, parallel, opposite, at a broad angle of dirergence, strougly marked like all the details of nervation, camptodrome, nerving in passing toward the borders and following them, by anastomos. ing by curves and nervilles, to the upper one; nervilles strong, at right angles to the medial nerve and to the secondaries, irregularly branch. ing aud anastomosing, forming large polygonal meshes.

The leaflet, broken at apex, is $8^{\mathrm{cm}} \operatorname{long}, 1 \frac{1}{2}$ to $2^{\mathrm{cm}}$ broad near the base, $3^{\mathrm{cm}}$ broad at the upper part where it is broken.

As yet I have seen nothing in the North American fossil flora to which this leaf might be related. It is comparable in all its characters, form, and nervation, to Aralia robusta (Sap. Sez. Fl., p. 386, Pl. x, fig. 7). It has also the aspect of leaves of Laurus, e.g., L. Reussii, L. primigenia var., but is quite distinct by its distant parallel secondaries. The leaflet, not entirely preserved, seems to be part of a compound leaf.

One specinen; Museum number, 2425.

\section{Magnolia Inglefieldi Heer.}

The description of the species in Heer (Fl. Arct., 1, p. 120) is as follows: "M. leaves large, coriaceous, smooth (levigati), very entire, ellip- 
tical; medial nerve thick; secondaries distant, flexuous, camptodrome, areas large reticulate."

It seems against reason to separate these fragments, which are large and numerous, and to form a new species. They agree well for the essential characters, the large size of the leaves, the thick medial nerve, the distant secondaries, the areas reticulate as in 876 and $876 a$, but they differ by the secondaries being stronger at a still more acute angle of divergence, less branched, following upward close to the borders, and the very thick nervilles. The base of the leaves is narrowed gradually (as in the fig. 1 of the Fl. Arct., Pl. xvIII), and the medial nerve is quite thick. It is evidently a variety of the species which, as represented by Heer, is extremely variable. One specimen, No. $877 a$, shows the leaf rounded to a point; the apex is not seen in any of Heer's leaves.

Twelve specimens; Museum number, 2511.

\section{Magnolia Hilgardiana Lx.}

The leaf finely preserved has the form and the nervation of the species so that identity appears undeniable. It differs somewhat, nevertheless, by the secondaries somewhat more curved in traversing the areas, and at a somewhat more acute angle of divergence. This, however, is of no importance, as the American specimen has, like that of Mississippi, the secondaries a little more oblique on one side than on the other. The more important difference is in the lower secondaries, which in the Mississippi leaves are more open toward the base, and this does not appear to be the case in No. 879, of which, however, the base is destroyed.

Two specimens; Museum number, 2510.

Magnolia californica Lx.

There are five fragments of this species differing slightly from the figures I have given of the species in Gold-bearing Gravels, pl. vi, fig. i. The characters are, however, well preserved in the much curved parallel secondaries, curving near the borders, and following them in simple areoles. The secondaries are simple; the nervilles very strong, also simple, straight, or undulate.

Five specimens; Museum number, 2508.

Laurus socialis $\mathrm{Lx}$.

Three specimens; Museum number, 2500.

Cinnamomum! Scheuchzeri Heer.

One specimen; Museim number, 2450.

Cornus hyperborea Heer. Plate xv, fig 3. (Heer, Fl. Foss. Arct., vol. ii, pt. iv, p. 4千6, Pi. Iv, figs. 3, 4.)

The description of Heer does not accord with the figures of his species loc. cit. He says: "Leaves elliptical, with few nerves; secondaries emerging at an acute angle of divergence, acrodrome, distant." From 
the two fragments figured, the nerves are not few nor distant, but close, parallel, numerous, simple, acrodrome, the upper ones nearly parallel to the medial nerve, which is comparatively narrow.

The leaf which I refer to the species, a fragment $14^{\mathrm{cm}}$ long, the base and the apex destroyed, has eight pairs of secondaries subopposite, the lowest less than $1^{\mathrm{cm}}$ distant, the upper ones $2 \frac{1}{2} \mathrm{~cm}$ at an angle of divergence of 40 to 45 degrees, same as marked in Heer's figures. This one is marked by transverse, simple, strong nervilles, which are not seen in the American specimens whose surface is quite smooth. This species is of the same type as Cornus Kelloggii (Lesqx., Fl. of the Aurif. Gravel, p. 23 , Pl. vI, fig 3 ,) which merely differs by the leaf broader (nearly round) the secondaries more distant, only four pairs, opposite, also simple, acrodrome. The specimen figured by Heer is from Atanekerdluck.

One specimen; Museum number, 2454.

Leguminosites, spec.

One specimen; Museum number, 2637.

Oreodaphne lithæformis, n. sp. Plate XIv, fig 4.

Leaf coriaceous, oblong.lanceolate, gradually narrowing and prolonged upward ; borders entire; medial nerve rigid ; secondaries thin, the lowest pair subopposite, the others few, alternate, distant, all at an acute angle of divergence, slightly curving in passing high up toward the borders, camptodrome, areolation in minute round areoles.

The leaf, only partly preserved, is $12 \frac{1}{2}{ }^{\mathrm{em}}$ broad, the upper part being: destroyed, $5 \mathrm{~cm}$ broad above the base, narrowed in gradually rounding to a short petiole; secondaries, fire pairs, the lowest and the upper only opposite, unequidistant, 2 to $2 \frac{1}{2} \mathrm{~cm}$ distant, but parallel, at an angle of divergence of 25 to 30 degrees. They run very high in gradually nearing the borders and disappear before reaching them.

The aspect of this leaf is much like that of species of Pèrsea, espe. cially $P$. caroliniana, var. assimilis, Sap. \& Mar., in Fl. de Meximienx. But its characters, taken altogether, relate it to Oreodaphne, especially the areolation and the presence of a kind of tumescence in the axils of some of the secondaries. Its nerration is that of a Litscea. Its nearest affinity is Oreodaphne Heerii Gaud., as figured in Sism. Mater., Pl. XxII, fig. 1, a leaf of which all the secondaries, even the lowest, are alternate at a very acute angle of divergence and running high up to the borders. The form of the leaf is different, as it is rather linear from above the base to the point where it is broken. By this form and the distant secondaries irregularly placed, it is most like Litsca expansa Sap. \& Mar. (Fl. de Gelinden, p. 68, Pl. XI, figs. 1, 2).

One specimen; Museum number, 2525.

\section{Oreodaphne Heerii Gaud.}

This is perhaps the same as the preceding species, showing only a fragment, the middle of a leaf with the pairs of opposite secondaries 
very distant and at the same degree of divergence as in the preceding species.

Quercus Moorii Lx.

Four specimens; Museum number, 2561.

Quercus Olafseni Heer.

One specimen ; Museum number, 2560.

Juglans rugosa Lx.

One specimen; Museum number, 2491.

Ficus appendiculata Heer.

One specimen; Museum number, 2470.

Phragmites oeningensis $\mathrm{Al}$. $\mathrm{Br}$.

Four specimens; Museum number, 2531.

\section{1.}

From Cape Lisbourne, Alaska. Collected by Mr. Henry D. Woolfe. Age probably Neocomian.

Ginkgo multinervis Heer. Plate Xvi, fig. 6. (Heer, Fl. Aret., vi, (2) p. 46, Pl. vIII, figs. $2 b, 3,4$; $\mathrm{Pl}$. Ix, f. $3 b$.)

Heer describes the species as leaves palmate, deeply lobate, narrowed toward the base, cuneate truncate at apex; nerves thin, numerous, very close. The specimens from Alaska agree entirely with the description and figures of Heer, l.c., except that he says of the lobes, that they are truncate at apex. They are truncate by erosion or breakage, but really obtuse as Heer has figured them, Pl. Ix, figs. 3, 6. The Alaska specimen is only better preserved.

One specimen; Museum number, 2482.

Baiera palmata Heer. Plate Xvi, figs. 4, 5. (Heer in Fl. Ost. Siberia, p. 115, Pl. xxvIII, figs. 2-a-d.)

The specimens from Alaska represent only the lower part of the leaves, which are entire to the middle or above, and there digitate, laciniate, the division of the laciniæ being merely seen in a sinus at a distance of $9^{\mathrm{cm}}$ from the base. In Heer's specimens it is mostly the upper part or the laciniæ which are preserved. A fragment of one of the laciniæ is $9^{\mathrm{em}}$ long, $1 \frac{1}{2} \mathrm{~cm}$ broad, broken at both ends. The characters are as described by Heer.

Five specimens ; Museum number, 2437.

Podozamites latipennis Heer. Plate xvi, figs. 2, 3.

The species is represented in many ingures by Heer (Fl. Arct., vi, (2) Pl. xIv, figs. 1-9). It is described (p. 42) as leaves (pinnæ) large; leaflets open, alternate, a little distant, long-lanceolate, 11 to $16^{\mathrm{mm}}$ broad, narrowed to the base, gradually narrowed to the apex; nerves thin, close parallel. 
There is no leaflet attached to rachis in the specimens from Alaska, only separate ones, the largest $11^{\mathrm{cm}} \mathrm{long}, 2^{\mathrm{cm}}$ broad; some much shorter and narrower with the nerves thick, $16^{\mathrm{cm}}$ in width, or as many as marked in Heel's figure. The base of the large leaflet is more narrowed and rounded, the oblique point of attachment being only 5 to $8^{\mathrm{mm}}$ while it is $1^{\mathrm{cm}}$ in Heer's tigure.

Three specimens; Museum number, 2540.

Zamites alaskana, n. sp. Plate x, fig. 4.

Fragment of a leaflet, obcordate or emarginate at the point of attachment, slightly enlarging upward to the middle where it is destroyed, and there $2 \mathrm{~mm}^{\mathrm{mm}}$ broad at $4^{\mathrm{cm}}$ distance from the base. At the point of attachment, $5^{\mathrm{mm}}$ broarl only and semilunar, it is marked with three slightly distinet undulations. The nerves are very tirin, parallel, a little less than $1^{\mathrm{mm}}$ distant or six in $5^{\mathrm{mm}}$ of wirlth. Its affinities are distantly marked with Jurassic species. (Zamites distractus Sap., Jurassic Fl.; Z. Benevieri Heer, Fl. Foss. Helv., iv, Pl. LII.)

One specimen; Museum number, 2622.

Pecopteris denticulata Heer.

One specimen; Museum number, 2526.

\section{Aspidium Oerstedi Heer.}

Arct. Fl., vi, p. 30, Pl. xxxıv, fig. 3, is represented by many specimens, some with large pinne and pinnules near the base : $f$ the fionds, others with narrow long strict pinnæ and pinnules similar to those of the upper part of the fronds.

Fourteen specimens; Museum number, 2434.

Asplenium Dicksonianum Heer.

One specimen; Museum number, 2435.

Asplenium Foersteri Deb. \& Ett.

One specimen; Huseum number, 2536.

Pinus! staratschini Heer.

One specimen; Museum number, 2533.

Chondrites filiciformis, n. sp. Plate Xvi, fig. 1 .

Frond cartilagineous or coriaceous by compression, shining on the surface; primary branches straight, linear; secondary divisions sparse, diverging nearly at right angles, subpinnately ramose in oblique or horizontal, short obtusely trilobate or long flexuous branchlets bearing irregular round or obtuse squamose lobes at their base or at their extremities.

The stone has some fragments of primary linear branches, one of them ouly bearing divisions, the first at right angles, nearly as thick as the primary stem with oblique or nearly horizontal subdivisions either short obscurely trilobate, or longer once lobate at base and bitrilobate at apex. 
This species has a great likeness to C. jugiformis Hosius \& Mark, Kreideform. of Westfal, Pl. xxvi, fig. 16, also in Deb. \& Ett., Kreide Fl. ron Aach., Pl. I, figs. 8, 9, or to Jurassic species. C. Dumortieri Heer, Fl. Foss. Helr., iv, Pl. XLIII, fig. 16, also related to Caulerpites. It may be a form of $C$.jugiformis Hosius.

One specimen; Museum number, 2448.

\section{2.}

Specimens from Greenland. Collected by Lieut. R. E. Peary, U. S. Nary; age, Miocene.

Rhamnus eridani Ung.

One specimen; Museum number, 2576.

Cornus ferox Ung.

One specimen; Museum number, 2453.

Ilex longifolia Heer.

One specimen; Museum number, 2485.

Magnolia Inglefieldi Heer.

Six specimens; Museum number, 2512.

Magnolia regalis Heer.

One specimen; Museum number, 2518.

Daphnogene Kanii Heer.

Two specimens; Museum number, 2460.

Tilia Malmgreni Heer.

One specimen; Nuseum number, 2619.

McClintockia Lyeilii Heer.

Eight specimens; Museum number, 2519.

McClintockia dentata. ?

One specimen; Museum number, 2520.

Populus arctica Heer.

Twelve specimens; Museum number, 2543.

Populus Richardsoni Heer.

Three specimens ; Museum number, 2548.

Populus monodon Lx.

Five specimens ; Museum number, 2447.

Salix grœnlandica Heer.

One specimen; Museum number, 2590.

Corylus insignis Heer.

One specimen; Museum number, 2456.

Corylus Mcquarryi Heer.

Sixteen specimens; Museum number, 2457.

Proc. N. M. $88-3$ 
Quercus ? grœnlandica ? Heer.

Specimen discarded.

Quercus Laharpii Gand.

Two specimens; Museum number, 2557.

Quercus Olafseni Heer.

Two specimens; Museum number, 2558.

Quercus platania Heer.

One specimen; Museum number, 2564.

Juglans acuminata $\mathrm{Al}$. Br.

Two specimens; Museum number, 2486.

Juglans rugosa $\mathrm{Lx}$.

Two specimens; Museum number, 2492.

Platanus Guillelmae Jöpp.

One specimen; Museum number, 25.37.

Zizyphus Meekii Lx.

One specimen; Museum number, 2623.

Sequoia brevifolia ? Heer.

One specimen; Museum number, 2611.

Sequoia Langsdorfii Heer.

Thirty-two specimens; Museum number, 2606.

Sequoia Langsdorfii var acuta.

Eleven specimens; Museum number, 2608.

Sequoia Langsdorfii var. angustifolia.

'Iwelve specimens; Museum number, 2609.

Glyptostrobus Ungeri Heer.

One specimen; Museum number, 2480.

Taxodium distichum miocenum Heer.

Eleven specimens; Museum number, 2615.

Taxodium distichum miocenum, var. angustifolium, Heor.

Two specimens; Museum number, 2616.

Taxodium Tinajorum Heer.

Four specimens; Musenm number, 2617.

Taxites Obriki Heer.

Eight specimens; Museum number, 2618.

Fagus Deucalionis Ung.

A number of small or medium sized, entire leaves, ovate, acuminate, rounded at base, with craspedodrome close parallel secondaries some. what curved in traversing the blade and strong parallel generally simple nervilles at right angles to the secondaries. The only relation of these leaves is with those of the Arctic flora, which Heer considers and de. 
scribes as Fagus deucalionis. They differ by the coriaceous texture, the secondaries more or less curved in traversing the blade, rigid, forming narrow rectangles; the borders entire, even in the upper part, and the acuminate apex longer and narrower than in Pl. IV, fig. 3, Nachtrage zum foss. fl. of Grœnland Fl. Arct., . . The affinity is so marked that I do not separate these leaves into a new species, but the differences are, however, evident. The rectangles formed by the nervilles are recognized even in numerous small fragments of these leaves.

13.

From Contra Costa County, Cal. Collected by Mr. H. W. Turner. Age, probably Pliocene.

Diospyros virginiana L., var. Turneri, n, var.

The leaves have the same form and size as those of $D$. virginiana Linn., and appear to represent the same species, differing merely by the lowest pair of secondaries at a more acute angle of divergence than those above. In D. virginiana the same character is also sometimes observ. able, but rarely indeed, and the difference in the direction of the lower secondaries is much less marked. There is no species of Diospyros in the present flora of California. A number of species, however, are now in the flora of Japan. These fossil leaves described here have also a degree of affinity to D. lotus, var. japonica (D. Japonica S. et Z.), but the basilar secondaries of the last species are parallel to those above it. Three specimens; Museum number, 2461.

Magnolia californica Lx.

One specimen; Museum number, 2509.

Laurus, $c f$. canariensis Heer.

Laurus, $c f$. Furstenbergi Heer.

Fragments discarded.

Viburnum, ef. rugosus Pers.

One specimen; Museum number, 2625.

Vitis, species?

One specimen; Museum number, 2626.

\section{4.}

Sam's Creek, Jackson County, Oregon. Mr. B. F. Dowele, collector. Salix Lavateri Al. Br.

One specimen; Museum number, 2592.

Sapindus angustifolius Lx.

Two specimens; Museum number, 2600. Several indeterminable fragments. 


\section{5.}

Specimens donated by Mr. J. B. Marcou, of the U. S. Geological Survey. Locality in doubt, but marked "Fossil Point, P. Y. Sheet."

Cratægus Marcouiana, n. sp. Plate xrv, fig. 2, xv, figs. 1, 2.

Leaves rather thin, elliptical, acuminate, entire or dentate from the middle upward; attenuate at base; medial nerve somewhat strong; secondaries few, distant, three to five pairs, oblique, angle of divergence 30 degrees, subopposite, parallel, the lower suprabasilar nervilles at right angles to the secondaries.

The three leaves figured appear at first as referable to two different species, but some intermediate fragments show their identity, as well as the form and the nervation. The leaves are comparable to those of Cratcegus Kornerupi Heer (Aret. Fl., vii, 2, p. 136, Pl. LXvir, fig. 1) and C. tenuipes Heer (ibid., Pl. LxxxiI, fig. 8), as well as to those of some living species like $C$. arborescens, $C$. mexicana, $C$. crusgalli, etc. The leares vary from 5 to $8^{\mathrm{em}}$ long and from $2 \frac{1}{2}$ to $4^{\mathrm{cm}}$ broad, with a slender petiole $1 \frac{1}{2} \mathrm{~cm}$ long, enlarged at the point of attachment.

Seren specimens; Museum number, 2458.

Cratægus Marcouiana, n. sp., var. subintegrifolia, n. var. Plate Xıv, fig. 2.

Two specimens; Museum number, 2459. Several fragments; worthless.

\section{6.}

Selma, Cherokee County, Tex. Collected by Mr. L. Johnson, of the U. S. Geological Survey.

Quercus furcinervis Rossm.

One specimen; Museum number, 2553.

Persea speciosa? Heer.

Une specimen; Museum number, 2629.

Laurus primigenia Ung.

Two specimens; Museum number, 2499.

Eucalyptus, Quercus, Laurus, etc.

Fragments.

$1 \%$.

From Bridgetown, N. J. Collected by Mr. J. B. Mareou, of the U. S. Geological Survey. Specimens very obscure; mostly undeterminable.

Liquidambar europæum $\mathrm{Al}$. Br.

One specimen; Museum number, 2639.

Laurus primigenia? Heer.

Five specimens; Museum number, 2610.

Laurus plutonia? Heer.

Four specimens; Museum number, 2644. 


\section{Populus Berggreni? Heer.}

Two specimens; Museum number, 2641.

\section{Proteoides acuta Heer.}

One specimen; Museum number, 2642.

Leguminosites phaseolites? Heer.

Two specimens; Museum number, 2643.

\section{8.}

Plants collected by Captain (since General) J. C. Frémont during the geographical survey of Oregon and north California in 18t3-'44. Described by James Hall in Frémont's " Exploring Expedition to the Rocky Mountains." (Doc. No. 166, Washington, 1845, pp. 304-307, Pls. I-III.) [The numbers given the specimens are the preliminary ones used by Professor Lesquereux during his examination. The regular Museum numbers are included in brackets.]

1, 1a. [2645.] Glossopteris phillipsii? Hall. Plate II, figs. 5, 5a, 5b, 5c.

This is remarkably similar in form of leaves and nervation to Glos. sochlamys transmutans Gard. \& Ett. (Brit. Eoc. Fl., Pl. III, fig. 3; XII, fig. 8). The specimens of Frémont show indistinctly nervilles between the lateral nerves composing irregular, square meshes. In fig. 8, Pl. XII, of Gard \& Ett., the leaf has the areolation obsolete and the lateral nerves split, not branching near the end as in the figure of Hall.

No. 2. [2646.]

Represents two leaves of the same size and character with the secondaries slightly defined or scarcely so, and the areolation a little more distinct in one of them.

No. 3. [2647.]

Has three fragments of leaves $a, b, c ; a$ is like a dicotyledonous plant in appearance, but the areolation is formed of branches at right angles to the secondaries, which look like nervilles, but are really divisions of the nerres as they are enlarged at their point of attachment. The same character is seen in $b$, and in this as in $c$, the ultimate areoles are pitted as in Hall's fig. $5 c$ of Pl. II, the same areolation is seen in the leaves of Dictyophyllum nilsoni (Nath. Wäxte from Falszö, Pl. v, fig. 2). No. 4, 4a. . [2648.]

A large specimen with one large leaf, size and form of Glossochlamys transmutans, $l$. $c$., with the areolation of a Chrysodium. The left side of the lamina is traversed by a single, curved secondary (?) nerve, which, however, does not appear as a nerve, as the meshes of the epidermis covers it interruptedly and independently of it. The other leaf, a fragment only, looks, at first sight, like a Ficus by its nervation. But here also the relation of the areoles to the secondaries and tertiaries is not like a subdivision by degrees of larger areas into smaller ones, but a chain or linking of branches constituting still a netting of irregularly round oblong areoles of the same type as in Podoloma polypodioides (Ett. \& Garrl, l. c., Pl. III, fig. 9). 
No. 5. [2649.]

Is in two fragments of a different leaf (figured, pl. ii, fig. 5l, of [Lall). It has the pitted areolation like Dictyophyllum mentioned above.

No. 6. [2650.]

A small fragment of Dictyophyllum or Clathropteris. It has no secondaries, but only large square areoles like Clathropteris.

The specimen representing fig. 4, of $\mathrm{Pl}$. II, of $\mathrm{Hall}$, is part of an ovate leaf, lanceolate pointed above and dentate on the borders, the second. aries entering the teeth. The figure is really that of a dicotyledonous leaf, but the specimen is not in the lot !

What seems to me to be conclusive of the Oölithic age of the plants is the number of fragments of small ferns referable to the genus Thrysopteris, of which Heer has described a number of species from the Jurassic in Jura Flora of Siberia, Pls. I, II; also in Portugal flora, and which are also described as Hymenophyllites lechenbyi in Zigno, Pl. IX figs. 3-5, and Pl. xI, figs. 1, 2. Plate I, fig. 4, of Hall, is like Cycadopteris heterophylla Zigno, and fig. 3 of Pl. II is like C. heerii Zigno. Those small ferns mixed upon small specimens are really Ö̈lithic type.

No. 7. [2651.] Sphenopteris trifoliata Hall, Plate II, figs. 2, 2d. It is a Thyrsopteris

No. 8. [2652.] Thrysopteris, with rootlets of ferns, named by Hall Trichopteri gracilis. Plate I, fig. 5.

No. 9. [2653.] Fragment of Thrysopteris, named by Hall Sphenopteris triloba. Plate I fig. 8.

Nos. 10, 11. [2654.] Pecopteris undulata Hall. They are not Pecopteris: nervation obsolete.

No. 12. [2655.] Glossopteris phillipsii Hall.

No. 13. Fragment; rachis of fern.

No. 14. Fragment; probably like $4 a$.

\section{9.}

"Fortieth parallel collection." Collector not known.

Acu trilobatum Sternb.

Eight specimens; Museum number, 2416.

Miscellaneous localities.

20 .

Ilex longifolia Heer. Cascades, Oregon. A. Haque, collector.

One specimen; Museum number, 2484.

Cinnamonium affine Lx. Carbon Station, Wyoming. A. Haque, collector.

One specimen; Museum number, 2449.

Cissus lobato-crenato? Lx. Carbon Station, Wyoming. A. Haque, collector.

One specimen; Museum number, 2451.

Salix Grœnlandica Heer. Carbon Station, Wyoming. A. Haque, collector.

One specimen; Museum number, 2591.

Sequsia Reichзzbashi Heər. Rock Creek, Wyoning. Collector unknown. 

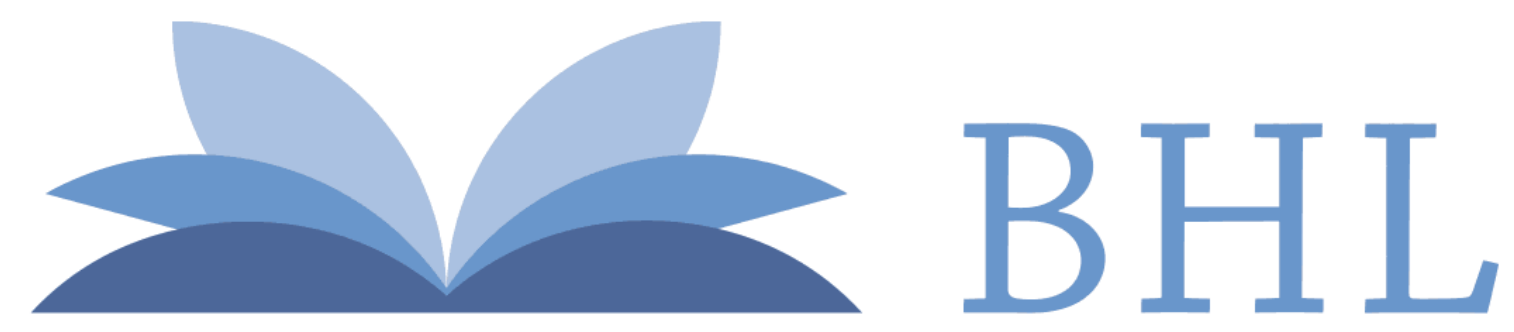

\section{Biodiversity Heritage Library}

Lesquereux, Léo. 1888. "Recent determinations of fossil plants from Kentucky, Louisiana, Oregon, California, Alaska, Greenland, etc., with descriptions of new species." Proceedings of the United States National Museum 11(679), 11-38. https://doi.org/10.5479/si.00963801.11-679.11.

View This Item Online: $\underline{\text { https://www.biodiversitylibrary.org/item/32566 }}$

DOI: https://doi.org/10.5479/si.00963801.11-679.11

Permalink: https://www.biodiversitylibrary.org/partpdf/40630

\section{Holding Institution}

Smithsonian Libraries

\section{Sponsored by}

Smithsonian

\section{Copyright \& Reuse}

Copyright Status: NOT_IN_COPYRIGHT

This document was created from content at the Biodiversity Heritage Library, the world's largest open access digital library for biodiversity literature and archives. Visit BHL at https://www.biodiversitylibrary.org. 